\title{
Consumer mobility and well-being among changing places and shifting ethnicities
}

\author{
Demangeot, Catherine , Broeckerhoff, A. , Kipnis, E. , Pullig, \\ Chris and Visconti, Luca M.
}

Postprint deposited in Curve June 2015

Original citation:

Demangeot, Catherine, Broeckerhoff, A. , Kipnis, E. , Pullig, Chris and Visconti, Luca M.

(2015) Consumer mobility and well-being among changing places and shifting ethnicities.

Marketing Theory, volume 15 (2): 271-278

http://mtq.sagepub.com/content/15/2/271.abstract

Publisher:

Sage

Copyright $\subseteq$ and Moral Rights are retained by the author(s) and/ or other copyright owners. A copy can be downloaded for personal non-commercial research or study, without prior permission or charge. This item cannot be reproduced or quoted extensively from without first obtaining permission in writing from the copyright holder(s). The content must not be changed in any way or sold commercially in any format or medium without the formal permission of the copyright holders.

CURVE is the Institutional Repository for Coventry University 


\section{Consumer mobility and well-being among changing places and shifting ethnicities}

\section{Catherine Demangeot}

(Department of Marketing) Strathclyde Business School, UK

\section{Aurelie Broeckerhoff}

(Centre for Social Relations) Coventry Business School, UK

\section{Eva Kipnis}

(Department of Marketing and Advertising) Coventry Business School, UK

\section{Chris Pullig}

(Department of Marketing) Hankamer School of Business, Baylor University, USA

\section{Luca M Visconti ${ }^{1}$}

(Department of Marketing) ESCP Europe, France

\section{Corresponding author:}

Catherine Demangeot, Department of Marketing, Strathclyde Business School, Stenhouse Building, 173 Cathedral Street, Glasgow G4 ORQ, UK

Email: catherine.demangeot@strath.ac.uk

\footnotetext{
${ }^{1}$ The authors are grateful to the participants of the Immigration, Culture and Ethnicity track of the 2013 Transformative Consumer Research Conference in Lille for their input, and especially to Wided Batat, Aliakbar Jafari and Andrew Lindridge for their comments on earlier drafts of this manuscript.
} 


\title{
Consumer mobility and well-being among changing places and shifting ethnicities
}

\author{
Abstract \\ (Market)places are spatial entities which individuals and groups might experience as \\ meaningful. By highlighting the role of place in ethnic consumer research, this article argues \\ that increased mobility and changing places render relatively stable notions of ethnicity \\ outdated. We identify three main trajectories to revitalize future research on ethnicity. First, \\ we demonstrate the need for research on ethnic identity to be underpinned by better \\ understanding of the role of place in identity processes. Second, we contend that the \\ established migration/acculturation paradigm should be replaced by the mobility/adaptiveness \\ paradigm. Third, we consider the profound effects of inter-ethnic contact among mobile and \\ immobile populations within shared places on individual and societal well-being.
}

\section{Keywords}

Place, ethnic identity, mobility, acculturation, well-being, transformative consumer research 


\section{Consumer mobility and well-being among changing places and shifting ethnicities}

Place is the evolving frontline in which ethnicity is felt, expressed, and negotiated (Lipsitz, 2007; Visconti, forthcoming). Increasing mobility multiplies the places people inhabit today, and thus fosters interest in when, where, and how ethnic identification becomes salient. In turn, increasing mobility causes place identities to evolve in tune with shifts among its transient and its more sedentary inhabitants. For instance, London's identity evolves as flows of new real estate buyers, long-term and expatriate residents, immigrant workers, students and other sojourners, all jostling with their own and others' ethnic identities, make an imprint on the city's identity. Such changes in places and shifts in ethnicity dynamics are pregnant with stress and conflict situations - both intrapersonal and interpersonal, and consequently the successful negotiation of such situations is key to consumer well-being. Centring on place, our article discusses shifting ethnicities, which we define as temporarily situated and permanently evolving ethnic identities resulting from people's repeated meaning exchanges within (multiple) places. Established acculturation theory does not encompass the notion of shifting ethnicities, implying that (1) acculturation to each place may be temporary and (2) acculturation becomes an iterative practice. Our 'emplaced' perspective on ethnicity research helps identify three main trajectories for rethinking the field in the interest of theoretical improvement and well-being.

\section{Trajectory 1: Towards greater interconnectedness between ethnicity and place}

We view places as spatial entities - physical and virtual - which are experienced as meaningful by individuals or groups (Canter, 1997; Groat, 1995; Massey, 1994). Place can be conceived at different scales: smaller scale places (public spaces, shops, neighbourhoods) represent the loci of lived experiences and practices, whereas larger scale places (countries) 
are 'imagined communities' (Anderson, 1983). Research in marketing has mostly focused on how larger scale places, namely nation-states and national cultures, affect individual practices (e.g. Steenkamp, 2001). By conceptualizing place as a frontline, we complement extant theories by (1) highlighting how local, concrete inter-ethnic engagement in smaller-scale places influences the construction of ethnicity and (2) indicating the structural interconnectedness of place and ethnicity whereby dwellers' ethnicities are reflected into lived place and, in turn, place grounds its inhabitants' and visitors' daily ethnicity negotiations.

As the theatres of social relationships, places are essential elements of 'our lived experience' (Sherry, 1998) and of 'being in the world' (Heidegger, 1962). Sense of place entails both an individual and a social level (Massey, 1994; Relph, 1976). Individually, places are the context where people experience and (re)negotiate their ethnic identity. Socially, places construct and are constructed by individuals and groups, and contribute to determine their situational ethnicity (Jeffers et al., 1996). As Massey argued (1994, cited in Oakes and Price, 2008: 262): 'What gives a place its specificity is not some long internalized history but the fact that it is constructed out of a particular constellation of social relations, meeting and weaving together at a particular locus'.

The interconnectedness between place and ethnicity has implications for research on ethnicity. Changes in place identities prompt changes in ethnic identities, and vice versa. Research is needed on how changing place identity affects consumer ethnic identity perceptions and well-being. For instance, does the pace of change affect the well-being of its more settled inhabitants? Further, when defining the identity of place, it is important to encompass both notions of roots (given identity's historically-grounded nature) and routes (given the imbrication of each place with other places its various inhabitants connect it with) 
(Clifford, 1997; Gustafson, 2001). Our field also needs a deeper understanding of how many residents' increased mobility affects place identity.

\section{Trajectory 2: Proposed paradigm shift from migration to mobility and from}

\section{acculturation to adaptiveness}

When considering ethnicity, marketing theory has so far mainly focused on migration (Askegaard et al., 2005; Peñaloza, 1989, 1994). We posit that today mobility is a more appropriate paradigm, recognising that: mobility, by now a common human experience (Appadurai, 1996; Bauman, 1998; Hannerz, 1996), can be long-term/permanent (migration), or short-term/occasional (tourism, business, education, and expatriation). Notably, people can occupy and be equally involved in different, even competing, places: Asian-Americans settled in the US may follow pre-election political debates in India (Appadurai, 1990); Danish transmigrants may spend holidays in their family’s Turkish village (Üçok Hughes and Kjeldgaard, 2006). Thus, mobility transforms places, inhabitants' experiences and ways people construct ethnicity.

Notably, transformations of place concern both mobile and immobile people (i.e. autochthonous and long-term immigrants). French anthropologist Marc Augé (2012) observes that globalisation has led to two paradoxical phenomena: at once, the world has become a city, designed by the same architects, occupied by the same companies offering the same products; concurrently, each city has become a world in itself, where global conflicts and contradictions are reproduced alongside ethnic, religious and socio-economic differences, or by the transience of some groups. Within a locale, interactions occur between 'mobile' and 'immobile' people: even those who do not move are exposed to increased diversity in daily life. For example Duruz (2005) documents the simultaneously alienating and enriching experience of autochthonous inhabitants of Haringey (London) and Newtown (Sydney) 
whose nearby main street consists mainly of ethnic food stores selling products unfamiliar to them. Contrary to the migration paradigm that focuses ethnicity discourse on long-term immigrants, in the mobility paradigm the ethnicity discourse concerns all ethnic groups, including frequent movers and autochthonous inhabitants.

Considering the impact of increasing mobility on ethnicity expands the research focus beyond acculturation to include an understanding of 'adaptiveness' (a consumer's ability to readily and successfully interact with the people, products, norms of multiple cultures in a variety of marketplace situations - Demangeot, 2014) for both mobile and immobile people (Bourhis et al., 1997). In particular, how do the more immobile groups who are at the receiving end of increasing ethnic diversity deal with this change? In terms of well-being, which coping mechanisms among different groups are adaptive or maladaptive?

\section{Trajectory 3: How the place-ethnicity interplay affects well-being}

Differences in conditions, motivations and types of mobility are likely to have important implications on people's ethnicity as they may impact dispositions towards the places that people visit or inhabit, and towards the different ethnicities they interact with there. Research has shown that rather than being decontextualized and objective, ethnicity is situational and felt (Stayman and Deshpande, 1989), malleable (Phinney, 1992), elective (Cornwell and Drennan, 2004; Kaufman, 1991); that is, a 'self-constructed understanding of oneself... that changes in response to developmental and contextual factors' (Phinney, 2005: 189).

Consequently, mobility and exposure to the consequences of mobility (increasing ethnic diversity in one's own context), can influence one's ethnic identification. Ethnic trajectories of both mobile and immobile consumers are becoming more complex and individualised, with a significant impact on the 'plasticity' of ethnicity (Visconti et al., 2014). 
Therefore, we acknowledge how individual patterns of mobility modify the role of place in ethnic identity construction. Yet we contend that, despite individual differences in people's dispositions, places today are the locus where individual well-being and social cohesion are lived and played out (Gustafson, 2001). We identify five implications for wellbeing and marketing theory that future research on ethnicity needs to explore. First, we argue that ethnicity and vulnerability require more sensitivity to situation and context. Undeniably certain groups commonly experience better/worse access to resources and thus higher/lower power and privilege over other groups because of their ethnicity (e.g. Adkins and Jae, 2010). Nonetheless, any consumer can experience ethnicity-related vulnerability (Broderick et al., 2011) when travelling or interacting with ethnically diverse consumers.

Second, from a social perspective, within fluid places the condition and status of a mobile person may be an asset rather than a weakness. For instance, second-generation British Ghanaian 'returnees' settling in Ghana can obtain far lower interest rates than indigenous Ghanaians through loans from British rather than African banks (Afua, 2013). Conversely, immobility may be experienced as feeling 'trapped in place' (Oakes and Price, 2008). According to acculturation theory (Berry, 2008; Peñaloza, 1994), the ability to operate with different cultural frames facilitates integration and psychological adjustment. We contend that as mobility shifts from migration to more temporary forms of sojourning (e.g. Bardhi et al., 2012; Figueiredo and Uncles, 2014), 'adaptiveness' rather than 'acculturation' becomes the key resource for mobile and immobile people. Other disciplines, for example intercultural research, higher education and international business (e.g. Deardorff and Jones, 2012; Johnson et al., 2006), have already explored various concepts related to adaptiveness, from which research on ethnicity could benefit.

Third, malleable identities can be adaptive or maladaptive (Sanchez et al., 2009). Sussman's (2000) model of cultural identity and its inherent notion of dynamic identity may 
be useful for further work on ethnic identity dynamics and well-being . At group level, integrated threat theory (Stephan et al., 1999), which suggests that animosity towards other groups depends on whether these groups are perceived as threatening one's position or oneself, can help explain origins of prejudice, and point to intervention strategies . Homophily (Rogers and Bhowmik, 1970), which posits that people perceived to be in similar 'otherness' situations may draw support from one another, brings to the fore the supportive interactions between members of different 'others'. The literature on sojourners (people inhabiting a place for a limited period) shows how foreign students draw support and resources from students from other countries, and how little contact they may have with host country nationals (Kashima and Loh, 2006; Montgomery and McDowell, 2009). Marketing theory's dominant focus on majority-minority ethnic relations has overshadowed these aspects.

Fourth, we argue that fluid, multi-ethnic places are the frontlines of intensified interethnic contact and that how individuals respond to (im)mobility will affect the adaptation experience. As places of particular interest to marketers, servicescapes (Sherry, 1998) can thus provide situations of conflict, opportunities to identify or associate with, and scope for learning and adaptation (Demangeot et al., 2013). Servicescapes are social places (Tombs and McColl-Kennedy, 2003) in which ethnic identity negotiations can happen as a result of consumers' interactions with staff, other consumers, products, practices or ideologies (Peñaloza, 2007). Rosenbaum and Montoya (2007) show how other consumers or service staff in the servicescape impact the well-being of consumers of different ethnicities and their sense of social belonging. We propose that two broad questions guide theoretical development: (1) What main conflict situations exist in the marketplace as a result of ethnic diversity, and how can marketers best manage them?; and (2) in which situations is multiethnic identity or engagement a source of stress, and when is it a source of enrichment? In 
this direction, transformative consumer research can draw from theories which are relational in nature. For instance, accommodation theory (Giles et al., 1991; Holland and Gentry, 1999) suggests that when a party is seen as taking it upon themselves to be accommodating, interactions are likely to be more productive. This theory is inter-cultural in nature; research shows how marketers' efforts to adapt to and accommodate the needs of ethnic minorities positively affect consumers' ethnic well-being and their dispositions towards these marketers (Huang et al., 2013; Karande, 2005; Peñaloza and Gilly, 1999).

Fifth, by studying ethnic identity through the lens of the networks and relations between the residents, sojourners, local authorities and commercial actors of a place, researchers are able to incorporate a wider range of variables linking mobility, integration and well-being (Vertovec, 2007).

\section{Conclusion}

We identify three main areas of development for future research on ethnicity: (1) connecting the exploration of ethnicity to place; (2) shifting from a migration to a mobility paradigm to acknowledge that ethnic identity concerns immigrants, mobile, and immobile people concurrently; and (3) considering how shifting places and ethnicities impact individual and societal well-being.

Also, we document their relevance from three perspectives: (1) from a social marketing perspective, the plurality of people - immigrants, mobile, and immobile persons inhabiting the same place has implications for well-being depending on the way their shared place and shifting ethnic identities are negotiated; (2) from a macromarketing perspective, adaptiveness, more than acculturation, questions how policy and education support development of this desirable competence for mobile and immobile populations; and (3) from 
a commercial marketing perspective, marketplace read as place in which ethnic identities are made and negotiated discloses opportunities for consumers and service providers. 


\section{References}

Adkins Natalie R and Jae H (2010) Marketplace vulnerability of limited English proficient consumers: Opportunities to increase knowledge in macromarketing. Journal of Macromarketing 30 (1): 93-104.

Afua H (2013) Le grand retour des enfants d'immigres. Courrier International, Hors Serie, 22.

Anderson BRG (1983) Imagined Communities: Reflections on the Origin and Spread of Nationalism. London: Verso.

Appadurai A (1990) Disjuncture and difference in the global cultural economy. Theory, Culture and Society 7 (2/3): 295-310.

Appadurai A (1996) Modernity at Large: Cultural Dimensions in Globalization. Minneapolis: University of Minnesota Press.

Askegaard S, Arnould EJ and Kjeldgaard D (2005) Postassimilationist ethnic consumer research: Qualifications and extensions. Journal of Consumer Research 32 (1): 160170.

Augé MA (2012) Pour une Anthropologie de la Mobilité. Paris: Payot \& Rivages.

Bardhi F, Eckhardt GM and Arnould EJ (2012) Liquid relationship to possessions. Journal of Consumer Research 39 (3): 510-529.

Bauman Z (1998) Globalisation: The Human Consequences. Cambridge: Polity.

Berry JW (2008) Globalisation and acculturation. International Journal of Intercultural Relations 32 (4): 328-336.

Bourhis RY, Moise LC, Perreault S and Senecal S (1997) Towards an interactive acculturation model: A social psychological approach. International Journal of Psychology 32 (6): 369-386. 
Broderick AJ, Demangeot C, Adkins NR, Ferguson NS, Henderson GR, Kipnis E, Johnson G, Mandiberg JM, Mueller RD, Pullig C, Roy A and Zuñiga M (2011) Consumer empowerment in multicultural marketplaces: Navigating multicultural identities to reduce consumer vulnerability. Journal of Research for Consumers (19.

Canter D (1997) The facets of place. In Moore GT and Marans RW (eds), Toward the Integration of Theory, Methods, Research, and Utilization. New York: Plenum, 109147.

Clifford J (1997) Routes; Travel and Translation in the Late Twentieth Century.

Cambridge,MA: Harvard University Press.

Cornwell TB and Drennan J (2004) Cross-cultural consumer/consumption research: Dealing with issues emerging from globalization and fragmentation. Journal of Macromarketing 24 (2): 108-121.

Deardorff DK and Jones E (2012) Intercultural competence: An emerging focus in international higher education. Thousand Oaks, CA: Sage.

Demangeot C (2014) The multiculturally adaptive consumer Working Paper Glasgow, UK: Strathclyde Business School.

Demangeot C, Adkins NR, Mueller RD, Henderson GR, Ferguson NS, Mandiberg JM, Roy A, Johnson GD, Kipnis E, Pullig C, Broderick AJ and Zúñiga MA (2013) Towards intercultural competency in multicultural marketplaces. Journal of Public Policy \& Marketing.

Duruz J (2005) Eating at the borders: Culinary journeys. Environment and Planning DSociety \& Space 23 (1): 51-69.

Figueiredo B and Uncles M (2014) Moving across time and space: temporal management and structuration of consumption in conditions of global mobility. Consumption Markets \& Culture): 1-16. 
Giles H, Coupland N and Coupland J (1991) Accommodation theory: communication, context, and consequences. In Giles $\mathrm{H}$ and Coupland $\mathrm{J}$ (eds), Contexts of Accommodation: Developments in Applied Sociolinguistics. Cambridge: Cambridge University Press.

Groat LN (1995) Giving Places Meaning. London: Academic Press.

Gustafson P (2001) Roots and routes: Exploring the relationship between place attachment and mobility. Environment and Behavior 33 (5): 667-686.

Hannerz U (1996) Transnational Connections: Culture, People, Places. London: Routledge. Heidegger M (1962) Being and Time. New York: Harper \& Row.

Holland J and Gentry JW (1999) Ethnic consumer reaction to targeted marketing: a theory of intercultural accommodation. Journal of Advertising Research 28 (1): 66-77.

Huang Y, Oppewal H and Mavondo F (2013) The influence of ethnic attributeson ethnic consumer choice of service outlet. European Journal of Marketing 47 (5/6): 877-898.

Jeffers S, Hoggett P and Harrison L (1996) Race, ethnicity and community in three localities. Journal of Ethnic and Migration Studies 22 (1): 111-126.

Johnson JP, Lenartowicz T and Apud S (2006) Cross-cultural competence in international business: Toward a definition and a model. Journal of International Business Studies 37 (4): 525-543.

Karande K (2005) Minority response to ethnically similar models in advertisements: An application of accommodation theory. Journal of Business Research 58): 1573-1580.

Kashima ES and Loh E (2006) International students' acculturation: Effects of international, conational, and local ties and need for closure. International Journal of Intercultural Relations 30 (4): 471-485.

Kaufman D (1991) Rachel's Daughters: Newly-Orthodox Jewish Women. New Brunswick, NJ: Rutgers University Press. 
Lipsitz G (2007) The racialization of space and the spatialization of race: Theorizing the hidden architecture of landscape. Landscape Journal 26): 10-23.

Massey D (1994) Space, Place and Gender. Cambridge: Polity Press.

Montgomery C and McDowell L (2009) Social networks and the international student experience: An international community of practice? Journal of Studies in International Education 13 (4): 455-466.

Oakes T and Price PL (2008) The Cultural Geography Reader. London and New York: Routledge.

Peñaloza LN (1989) Immigrant consumer acculturation. In Advances in Consumer Research, $16,110-118$.

Peñaloza LN (1994) Atravesando fronteras/Border crossings: A critical ethnographic exploration of the consumer acculturation of Mexican immigrants. The Journal of Consumer Research 21 (1): 32-54.

Peñaloza LN (2007) Mainstreet U.S.A. revisited: Market targeting, politics, Latino/a consumer culture, and community. International Journal of Sociology and Social Policy 27 (5/6): 234-249.

Peñaloza LN and Gilly MC (1999) Marketer acculturation: The changer and the changed. Journal of Marketing): 84-104.

Phinney JS (1992) The multigroup ethnic identity measure: A new scale for use with diverse groups. Journal of Adolescent Research 7 (2): 156-176.

Phinney JS (2005) Ethnic identity in late modern times: A response to Rattansi and Phoenix. Identity 5 (2): 187-194.

Relph E (1976) Place and Placelessness. London: Pion.

Rogers EM and Bhowmik DP (1970) Homophily - heterophily: Relational concepts for communication research. Public Opinion Quarterly 34 (1): 523-538. 
Rosenbaum MS and Montoya DY (2007) Am I welcome here? Exploring how ethnic consumers assess their place identity. Journal of Business Research 60 (3): 206-214.

Sanchez DT, Shih M and Garcia JA (2009) Juggling multiple racial identities: Malleable racial identification and psychological well-being. Cultural Diversity \& Ethnic Minority Psychology 15 (3): 243-254.

Sherry JFJ (1998) Servicescapes: The Concept of Place in Contemporary Markets. Chicago: NTC Business Books.

Stayman DM and Deshpande R (1989) Situational ethnicity and consumer behavior. Journal of Consumer Research 16 (3): 361-371.

Steenkamp J-BEM (2001) The role of national culture in international marketing research. International Marketing Review 18 (1): 30-44.

Stephan WG, Ybarra O and Bachman G (1999) Prejudice toward immigrants. Journal of Applied Social Psychology 29 (11): 2221-2237.

Sussman NM (2000) The dynamic nature of cultural identity throughout cultural transitions: Why home is not so sweet. Personality and Social Psychology Review 4 (4): 355373.

Tombs A and McColl-Kennedy JR (2003) Social-servicescape conceptual model. Marketing Theory 3 (4): 447-475.

Üçok Hughes M and Kjeldgaard D (2006) Consumption in transnational social spaces: A study of Turkish transmigrants. In Karin E and Helene B (eds), European Advances in Consumer Research, 7. Provo: Association for Consumer Research, 431-437.

Vertovec S (2007) Super-diversity and its implications. Ethnic and Racial Studies 30 (6): 1024-1054. 
Visconti LM (forthcoming) Emplaced ethnicity: The role of space(s) on migrants' acculturation. In Jamal A, Laroche M and Peñaloza L (eds), The Routledge Companion on Ethnic Marketing. London: Routledge.

Visconti LM, Jafari A, Batat W, Broeckerhoff A, Dedeoglu AÖ, Demangeot C, Kipnis E, Lindridge A, Peñaloza LN, Pullig C, Regany F, Ustundagli E and Weinberger MF (2014) Consumer ethnicity three decades after: A TCR agenda. Paris. 